\title{
Cross-cultural adaptation of the scale National Emergency Department Overcrowding Score (NEDOCS) for use in Brazil
}

\author{
Adaptação transcultural da escala National Emergency Department \\ Overcrowding Score (NEDOCS) para uso no Brasil \\ Adaptación transcultural de la escala National Emergency Department \\ Overcrowding Score (NEDOCS) para uso en Brasil
}

\section{Henrique Meirelles Boldoria Rosane Mortari Ciconet ${ }^{a}$ Karin Viegas $^{\mathrm{b}}$ Rafaela Schaefer ${ }^{\mathrm{a}}$ Márcio Neres dos Santos ${ }^{c}$}

How to cite this article: Boldori HM, Ciconet RM, Viegas K, Schaefer R, Santos MN. Cross-cultural adaptation of the scale National Emergency Department Overcrowding Score (NEDOCS) for use in Brazil. Rev Gaúcha Enferm. 2021;42:e20200185 doi: https://doi.org/10.1590/19831447.2021.20200185
Universidade do Vale do Rio dos Sinos (UNIIINOS). Porto Alegre, Rio Grande do Sul, Brasil.

• Universidade Federal de Ciências da Saúde de Porto Alegre (UFCSPA). Porto Alegre, Rio Grande do Sul, Brasil.

Pontificia Universidade Católica do Rio Grande do Sul (PUCRS). Porto Alegre, Rio Grande do Sul, Brasil.

\section{ABSTRACT}

Objective: To describe the process of translation and cross-cultural adaptation of the National Emergency Department Overcrowding Score (NEDOCS) into the Portuguese language for use in Brazil.

Method: Methodological study of translation and cross-cultural adaptation into the Portuguese language of Brazil, founded in the recommendations of the Guidelines for the Process of Cross-Cultural Adaptation of Self-Report Measures, that comprise the stages of initial translation; synthesis of the translations; back-translation; committee of experts; pretesting and introduction of the scale to the author.

Results: The Portuguese-adapted scale presented semantic, idiomatic, experimental and conceptual equivalence with the original one; the total value of the Cronbach's Alpha was -0,401 due to the non-positive intercorrelation among the scale items.

Conclusions: The NEDOCS scale has proved to be a reliable instrument to be utilized in the real-time monitoring of the assignment of emergency services. Thus, it contributes to the managerial and assistance processes besides providing health indicators.

Keywords: Validation study. Emergencies. Emergency service, hospital.

\section{RESUMO}

Objetivo: Descrever o processo de tradução e adaptação transcultural, para a língua portuguesa, da escala National Emergency Department Overcrowding Score (NEDOCS) para uso no Brasil.

Método: Estudo metodológico de tradução e adaptação transcultural para a língua portuguesa do Brasil, fundamentado nas recomendações do Guidelines for the Process of Cross-Cultural Adaptation of Self-Report Measures, compreendendo as etapas de tradução inicial; síntese das traduções; retrotradução; comitê de especialistas; pré-teste e submissão da escala ao autor. Resultados: A escala adaptada para o português apresentou equivalência semântica, idiomática, experimental e conceitual com 0 original; 0 valor total do Alpha de Cronbach foi de -0,401, devido a não intercorrelação positiva entre os itens da escala.

Conclusões: A escala NEDOCS demonstrou ser um instrumento confiável, para ser utilizada no monitoramento em tempo real da lotação dos serviços de emergência, contribuindo nos processos gerenciais e assistenciais e fornece indicadores em saúde.

Palavras-chave: Estudo de validação. Emergências. Serviço hospitalar de emergência.

\section{RESUMEN}

Objetivo: Describir el proceso de traducción y adaptación transcultural, para la lengua portuguesa, de la escala National Emergency Department Overcrowding Score (NEDOCS) para el uso en Brasil.

Método: Estudio metodológico de traducción y adaptación transcultural al portugués de Brasil, basado en las recomendaciones del Guidelines for the Process of Cross-Cultural Adaptation of Self-Report Measures, que incluye las etapas de traducción inicial; síntesis de las traducciones; traducción de respaldo; comité de expertos; prueba previa y presentación de la escala al autor.

Resultados: La escala adaptada al portugués presentó equivalencia semántica, idiomática, experimental y conceptual con respecto al original; el valor total del Alpha de Cronbach fue de -0,401 debido a que no hubo intercorrelación positiva entre los elementos de la escala.

Conclusiones: La escala NEDOCS ha demostrado ser un instrumento confiable útil para el monitoreo en tiempo real de la asignación de los servicios de urgencia, y, por lo tanto, contribuye en los procesos gerenciales y asistenciales, además de proporcionar indicadores de salud.

Palabras clave: Estudio de validación. Urgencias médicas. Servicio de urgencia en hospital. 


\section{口INTRODUCTION}

Hospital emergency departments (EDs) in developing countries are experiencing an increase in patient volume, which causes limitations to access and overcrowding ${ }^{(1)}$. In these services, overcrowding impacts the quality of care, making health professionals more susceptible to commit errors, with impact in their physical and mental health, and increased wait time for patients ${ }^{(2)}$.

Overcrowding can result in increased financial expenses (e.g. materials and medications) for health institutions ${ }^{(3)}$, reduce effectiveness and quality of care and is associated with a decline in quality indicators due to the ineffective supervision of health professionals, with patients leaving the ED without being seen, consequent deaths, among other factors ${ }^{(4)}$.

Measures to solve the problems caused by overcrowding include reducing the length of stay in ED and improving the service flow, which can contribute to the improvement of the quality of care associated with coordinated efforts between professional managers and other sectors of the health institution ${ }^{(5)}$.

In this context, the use of tools in ED management can promote efficiency, dynamism and resoluteness regarding overcrowding. Users would then feel more satisfied with the shorter wait time and with the care provided to them, which includes being informed and clarified about their health status (2).

The National Emergency Department Overcrowding Score (NEDOCS) scale, developed by Weiss and colleagues, has been used worldwide to assess ED overcrowding. The tool converts a set of variables into a score that correlates with the degree of overcrowding perceived by the professionals performing their duties at that moment. Thus, it is used to identify the causes of overcrowding and guide the implementation of measures to solve the problem. The scale has a range of 0-200 points, with a score of 101 or more considered overcrowding ${ }^{(6)}$.

The NEDOCS is described in the international literature as an objective tool that helps to make the health team aware of the need to implement actions tailored to the needs of each hospital's ED, with the purpose of improving the quality of care services and ensuring the safety of patients and staff(7).

In Brazil, the use of NEDOCS in hospital emergency services has significantly improved the indicators related to ED overcrowding ${ }^{(8)}$. However, its use was not preceded by a process of translation and cross-cultural adaptation that seeks to achieve the semantic and content reliability necessary for using the instrument in another country. To ensure equivalence between the original version and the intended version, the tool must not only be well translated from a linguistic point of view, but also culturally adapted, considering specificities such as the organization of health services and system, for example, even in objective scales calculated by formulas, as they contain statements ${ }^{(9)}$.

The NEDOCS scale is easy to use and makes it possible to monitor ED occupancy levels, contributing to decision-making related to care flows in the sector, which results in greater fluidity of care and reduced length of stay.

Therefore, the present study formulated the following guiding question: how should a continuous and updated monitoring of the levels of ED occupancy be carried out? It is estimated that the availability and use of a tool that allows measuring one of the main issues in emergency services, will contribute to the organization and improvement of the quality of care in the services. Hence the present study aimed to describe the process of translation and cross-cultural adaptation, into Portuguese, of the National Emergency Department Overcrowding Score (NEDOCS) scale for use in Brazil.

\section{$\square$ METHOD}

Methodological study that is part of a project contemplated under the CAPES/COFEN Agreement, Notice no 27/2016, attached to the Postgraduate Professional Master's Program in Nursing of Universidade do Vale do Rio dos Sinos, which addresses the qualification of Nursing Care Systematization and values the potential of nurses' participation in improving care processes ${ }^{(10)}$.

The study was carried out in a municipal hospital in the Metropolitan Region of Porto Alegre, Rio Grande do Sul. The hospital is a medium and high-complexity referral center and provides health services under the Unified Health System (SUS) and in other hospital emergency services in Brazil. The study aimed to was to carry out a cross-cultural adaptation for the Portuguese language and the validation of the National Emergency Department Overcrowding Score (NEDOCS) scale for use in Brazil. The referred instrument was chosen as a tool for the improvement of the care process in Emergency Services because it is easy to use and free of charge.

The NEDOCS scale is an instrument developed by Steven Weiss, professor of medicine at the University of New Mexico, applied in eight ED services of educational institutions and subsequently validated from the point of view of doctors and nurses. The variables assessed by the scale concern the number of beds in ED, occupancy, wait times, total capacity of beds in the hospital where the ED is located, among other aspects (Chart 1). The total number of points is added in order to obtain the final score on a 0-200 scale whose values are 
stratified according to occupancy rates, with overcrowding starting at score $101^{(11)}$.

The NEDOCS score is calculated using the formula (14): NEDOCS $=-20+85.8 *(a)+600 *(b)+13.4 *(c)+.93 *(d)$ $+5.64 *(e)$, where $a=$ Total patients in ED/ total beds; $b=$ Total number of holdovers/admits in ED/Total number of ED beds; $\mathrm{c}=$ Vent Patients in $\mathrm{ED} ; \mathrm{d}=$ Longest admit boarding time in ED; e = Hrs longest wait in WR (last bed time); and the symbol ${ }^{* \prime}=$ multiplication.

In some cases, hospital institutions have their own criteria for overcrowding defined by restriction protocols. Therefore, a correction factor of 0.5 was applied to establish a threshold for the use of the NEDOCS scale. Using the correction factor to draw the overcrowding threshold of 101 (Overcrowded), based on threshold values of the variables of the tool, the NEDOCS scale can be adapted for use in the analysis of the variables, according to pre-defined criteria for overcrowding.

Previous authorization was obtained from the author for the cross-cultural translation process of the NEDOCS scale. The study was based on the recommendations of the Guidelines for the Process of Cross-Cultural Adaptation of Self-Report Measures ${ }^{(9)}$, according to the steps described below:

Initial translation: the NEDOCS scale was translated into the Brazilian Portuguese language independently by two bilingual translators with different backgrounds, called $\mathrm{T} 1$ and $\mathrm{T} 2$. The translator who performed $\mathrm{T} 1$ is a healthcare professional; the other translator had no knowledge in the area. Both translations were returned to the researcher.

Synthesis of the translations: The two translations (T1 and T2) were analyzed and compared by the two translators, the advisor and the researcher to assess discrepancies/equivalences, need for correcting any spelling errors, and the Portuguese synthesis version (VSP) was produced by consensus.

Back-translation: The VSP was back-translated to the original language independently by two different bilingual translators (native speakers of the English language) totally blind to the original version and who had no background in the health care area. A fifth translator made the consensus between the two back-translations, elaborating the final back-translated version (FBTV).

Total Patients in ED- The number of total patients in the ED at the time the score is calculated. This includes all patients in all areas including waiting patients, Fast Track patients, etc.

ED Beds - The total number of ED beds including hallways, chairs, fast track and other beds that can be used to serve patients at the time the score is calculated.

Admits - The number of holdovers/admits, in the ED, at the time the score is calculated.

Total Hospital Beds - The total number of hospital beds. Most implementations use the number of licensed beds that can be used in case of a disaster.

Vent patients in ED - The number of patients on ventilators/respirators (including BIPAP) in the ED at the time the score is calculated.

Longest admit boarding time (in ED) - The longest admit holdover/boarding (in hours) at the time the score was calculated. (Example: $3.5=3$ hours 30 minutes).

Hrs longest wait in WR (Last Bed Time) - The wait time (in hours) from arrival to bed for the last patient called for a bed (Example: $1.33-1$ hour and 20 minutes).

00 to 20 - Not Busy / 21 to 60 - Busy / 61 to 100 - Extremely busy, but not overcrowded / 101 to 140 Overcrowded / 141 to 180 - Severely overcrowded / 181 to 200 - Dangerously overcrowded

Chart 1 - National Emergency Department Overcrowding Score (NEDOCS). Porto Alegre, RS, 2019 Source: Research data, 2019. 
Committee of experts: Professionals from several Emergency Services (ED) in the Metropolitan Region of Porto Alegre were invited to compose the committee of experts, and the following inclusion criteria were adopted: be a nurse or physician with experience in the emergency area for 1 year of experience or more; for nursing professors, the inclusion criteria were as follows: be undergraduate or graduate professors, proficient in English and with experience in scientific methodology. In this step, semantic, idiomatic and conceptual equivalence between the VSP, the FBTV and the original instrument was assessed. Any doubts that arose regarding the interpretation of the meanings of the variables were referred to the author of the scale, through questions formulated by the group. After the clarifications provided by the author and the translators who participated in the initial translation and synthesis process, the version translated into Portuguese (VTP) was elaborated for content validation, through the Content Validity Index $(\mathrm{CVI})^{(12)}$. After detailed analysis of each item and its respective concepts, the professionals were able to select a score between 1 and 4 , regarding the clarity of the translation of the variables. A minimum acceptable rate of 0.90 was considered, based on the sum of the number of "clear" (3) and "very clear" (4) responses, divided by the total number of responses, generating the final version translated into Portuguese (VFP) ${ }^{(13)}$.

Pretesting: For the application of the pre-test, a form was created to fill in the variables of the VFP, which was applied in the hospital where the study was conducted. The pre-test was applied from June 29 to July 10, 2019, in the hospital institutions ED. Snowball sampling was used. It is a nonprobability sampling technique, according to which the VFP was applied by professionals from emergency departments from different regions of Brazil who, in turn, recruited other participants and so on. The data necessary for the NEDOCS formula was sent to the researchers. A 5-point Likert scale was also sent to the professionals, which ranged from "I totally agree" to "I totally disagree, to assess the clarity in the applicability of the instrument ${ }^{(11)}$.

The last step of the study consisted in submitting the scale to the author. Thus, all reports related to the process of validation and cross-cultural adaptation of the NEDOCS scale were sent to the author, via e-mail.

The variables were described as absolute and relative frequencies and associated by Chi-square test, along with the analysis of adjusted residuals. To assess the association between the variables on the NEDOCS scale, Spearman correlation coefficient was applied, with a significance level of $5 \%$, and to assess the internal consistency of the scale, the Cronbach's alpha coefficient was used. Cronbach alpha valued of 0.70 or higher indicate acceptable internal consistency. Analyzes were performed using the Statistical Package for the Social Sciences (SPSS) version 21.0.

The study was approved by the Ethics and Research Committee of UNISINOS, under protocol no 03657718.5.0000.5344. The participants received electronic Informed Consent Forms, and anonymity and confidentiality of data were guaranteed.

\section{RESULTS}

Content validation, for the definition of the final Portuguese version of the scale, was performed through the Content Validation Index (CVI), by 42 professionals, as follows: 38 (90.5\%) nurses, 2 (4.8\%) physicians, 1 (2.4\%) hospital administrator and 1 (2.4\%) physiotherapist. Regarding the health care institutions, 38.0\% (16) professionals worked in philanthropic institutions or institutions attached to the SUS, (13) worked in private institutions and 31.0\% (13) worked in public institutions.

A minimum CVI of 0.90 (mean $=0.945$ ) was obtained with the use of Likert scale, considering the calculation of responses 3 and 4 of the form. Therefore, the final version translated into Portuguese (VFP) was validated and consolidated for application as a pre-test (Table 1).

Thus, the Final Portuguese Version (VFP) is shown in chart 2.

In total, 107 applications of the Final Portuguese version (VFP) of NEDOCS were performed, and the figures were calculated to determine the results. Table 2 includes the results of Spearman's correlation coefficients. 
Table 1 - Content Validity Index for the translations of the variables of the scale, Porto Alegre, Brazil

\begin{tabular}{|c|c|c|}
\hline Variable / Responses & $n=42$ & CVI \\
\hline \multicolumn{3}{|c|}{$1^{\text {st }}$ Variable - Total patients in ED } \\
\hline 1. Not clear & $0(0)$ & \multirow{5}{*}{0.90} \\
\hline 2. Unclear & $4(9.5)$ & \\
\hline & & \\
\hline 3. Clear & $9(21.4)$ & \\
\hline 4. Very clear & $29(69)$ & \\
\hline \multicolumn{3}{|c|}{$2^{\text {nd }}$ Variable - ED beds - n (\%) } \\
\hline 1. Not clear & $0(0)$ & \multirow{5}{*}{0.95} \\
\hline 2. Unclear & $2(4.7)$ & \\
\hline & & \\
\hline 3. Clear & $12(28.6)$ & \\
\hline 4. Very clear & $28(66.7)$ & \\
\hline
\end{tabular}

$3^{\text {rd }}$ Variable - Total number of holdovers/admits, in the ED - n (\%)

$\begin{array}{ll}\text { 1. Not clear } & 0(0)\end{array}$

2. Unclear $1(2.4)$

3. Clear $12(28.6)$

4. Very clear 29 (69)

$4^{\text {th }}$ Variable - Total hospital beds $-\mathrm{n}(\%)$

$\begin{array}{ll}\text { 1. Not clear } & 0(0)\end{array}$

2. Unclear $2(4.8)$

3. Clear $19(45.2)$

4. Very clear $21(50)$

$5^{\text {th }}$ Variable - Vent patients in ED $-\mathrm{n}(\%)$

$\begin{array}{ll}\text { 1. Not clear } & 0(0)\end{array}$

2. Unclear $1(2.4)$

$\begin{array}{ll}\text { 3. Clear } & 10(23.8)\end{array}$

0.98

4. Very clear $31(73.8)$ 
Table 1 - Cont.

$6^{\text {th }}$ Variable - The longest admit boarding time in ED - n (\%)

1. Not clear

2. Unclear

3. Clear
$21(50)$

$19(45,2)$

$7^{\text {th }}$ Variable - Hrs longest wait in WR (Last Bed Time) $-\mathrm{n}(\%)$

1. Not clear

2. Unclear

3. Clear

4. Very clear
23 (54.8)

15 (35.7)
Legend - n (\%)
1. Not clear
2. Unclear
3. Clear
14 (33.3)
4. Very clear
$26(61.9)$

Source: Research data, 2019.

When the associations between the items of the scale were evaluated, in statistical analysis, it was found that "Total hospital beds" was not positively and significantly associated with any item on the scale, except for "Total number of holdovers/admits, in the ED", although the correlation was weak.

Moreover, the item "Hrs longest wait in WR (Last Bed Time)" is inversely associated with 3 of the items on the scale, namely, longest admit boarding time in ED (in hours), "Total number of holdovers/admits, in the ED" and "ED Beds (formal and informal)". This draws attention to the independence between the values of the variables of the NEDOCS scale, as these variables are scored independently and are related to specific aspects of each ED situation where they are often fixed or even inversely proportional.
Thus, the value obtained in the calculation of Cronbach's alpha with seven items was -0.401 due to the non-positive correlation between the items of the scale (Table 2). If the items "Total hospital beds", "Longest admit boarding time in ED (in hours)" and "Hrs longest wait in WR (Last Bed Time)" were removed, as they are inversely correlated, Cronbach's Alpha value would be 0.67 , very close to the ideal value for internal consistency $(0.7)^{(16)}$. However, it is not possible to exclude items to achieve an ideal value for internal consistency, due to the importance of maintaining all variables for the calculation of ED capacity levels, and because an exact formula was developed to obtain results within the proposed range, that is, from 0 to 200. Therefore, assessment by Cronbach's Alpha is not adequate for the analysis of reliability of the NEDOCS scale. 
Número total de pacientes em atendimento no Serviço de Emergência - O número total de pacientes em atendimento no Serviço de Emergência, em qualquer tipo de acomodação.

Acomodações no Serviço de Emergência - Número total de acomodações formais e informais no Serviço de Emergência incluindo macas, poltronas, cadeiras e camas, ou seja, todas as acomodações onde os pacientes podem e/ou estão sendo atendidos.

Total de pacientes com prescrição de internação no Serviço de Emergência - O número total de pacientes com prescrição de internação que permanecem em acomodações (formais e informais) no Serviço de Emergência, aguardando leito para a transferência.

Número de leitos (oficiais) do hospital destinados ao Serviço de Emergência - O número de leitos (oficiais) do hospital destinados ao Serviço de Emergência, distinguindo leitos adultos e pediátricos.

Pacientes em ventilação - O número de pacientes em ventilação invasiva/não invasiva no Serviço de Emergência, no momento da coleta da informação.

Maior tempo de permanência de um paciente com prescrição de internação no Serviço de Emergência (em horas) - O maior tempo de permanência (em horas) de um paciente no Serviço de Emergência com prescrição de internação, até o momento em que a escala é aplicada.

Tempo de espera aguardado pelo último paciente de maior risco, para o primeiro atendimento médico (em horas) - O tempo de espera (em horas) aguardado pelo último paciente de maior risco até o primeiro atendimento médico, no momento em que a escala é aplicada.

00 a 20 - Desocupado / 21 a 60 - Ocupado / 61 a 100 - Extremamente ocupado, mas não superlotado / 101 a 140 - Superlotado / 141 a 180 - Severamente superlotado / 181 a 200 - Perigosamente superlotado

Chart 2 - Final version of the NEDOCS scale translated into Portuguese (VFP). Porto Alegre, RS, 2019 Source: Research data, 2019.

The association of variables with the classification of the NEDOCS scale is shown in Table 3.

There was a statistically significant association between type of hospital and measurement of overcrowding levels using the NEDOCS scale $(p<0.001)$, and the hospital where the study was conducted had a significantly higher percentage of the maximum overcrowding score (above 180) compared to other hospitals. There was also a statistically significant association between shift and overcrowding levels ( $p<0.001$ ): the morning shift had a higher percentage of the maximum score in the "dangerously overcrowded" category and the afternoon shift had a higher percentage in the "severely overcrowded" classification compared to the others. The night shift showed a significantly higher percentage in the category "extremely busy, but not overcrowded".

Finally, there was a significant association with the type of institution ( $p<0.001$ ), and public institutions had a significantly higher percentage of the "dangerously overcrowded" category compared to the others. Philanthropic and private institutions had a significantly higher score in the "overcrowded","severely overcrowded" and "without overcrowding (busy and extremely busy, but not overcrowded)"categories, respectively, compared to the others.

The highest percentage of evaluations was obtained in the "dangerously overcrowded" category, with the maximum score in 42 of the applications (Graph 1).

\section{DISCUSSION}

ED Overcrowding is a serious and growing problem that threatens the ideal quality of care model targeted by health systems. Studies indicate that long hospital stays and the lack of hospital beds available for these services are the main causes for overcrowding, which leads to reduction in the quality of care $^{(17-18)}$. 
Table 2 - Correlation between the items on the NEDOCS scale using Spearman's correlation coefficient. Porto Alegre, Brazil

\begin{tabular}{|c|c|c|c|c|c|c|c|}
\hline Items & (1) & (2) & (3) & (4) & (5) & (6) & (7) \\
\hline Total Patients in ED (1) & - & $0.63^{* * *}$ & $0.64^{* * *}$ & 0.02 & $0.42^{* * *}$ & $0.51^{* * *}$ & -0.04 \\
\hline $\begin{array}{l}\text { ED Beds (formal and } \\
\text { informal) (2) }\end{array}$ & - & - & $0.59^{* * *}$ & 0.01 & $0.24^{*}$ & $0.46^{* * *}$ & $-0.24^{*}$ \\
\hline $\begin{array}{l}\text { Total number of } \\
\text { holdovers/admits, } \\
\text { in the ED (3) }\end{array}$ & - & - & - & $0.22 *$ & $0.44^{* * *}$ & $0.56^{* * *}$ & $-0.20^{*}$ \\
\hline Total hospital beds (4) & - & - & - & - & $-0.25^{* *}$ & -0.17 & 0.1 \\
\hline Vent patients in ED (5) & - & - & - & - & - & $0.62^{* * *}$ & -0.14 \\
\hline $\begin{array}{l}\text { Longest admit boarding } \\
\text { time in ED (in hours) (6) }\end{array}$ & - & - & - & - & - & - & $-0.46^{* * *}$ \\
\hline $\begin{array}{l}\text { Hrs longest wait in WR } \\
\text { (Last Bed Time) (7) }\end{array}$ & - & - & - & - & - & - & - \\
\hline
\end{tabular}

Source: Research data, 2019

${ }^{*} p<0.05 ;{ }^{* *} p<0.01 ;{ }^{* * *} p<0.001$

In the present study, the high scores in overcrowding categories in the morning and afternoon shifts demonstrate that most people seek ED services mostly during daytime hours, possibly because it is easier for the population to access the services in this period.

The prevalence of the maximum overcrowding category (dangerously overcrowded) in public institutions indicates the search for resoluteness of care by users of the Unified Health System (SUS), due to the possibility of obtaining faster diagnosis and treatment in emergency care. The reduced capacity of primary care to assist these patients indicates the need for investments in health policies aimed at preventing diseases, in order to reduce overburdening of tertiary care facilities, as well as raising public awareness of the true role of emergency services ${ }^{(19)}$

At the hospital in the Metropolitan Region of Porto Alegre, Rio Grande do Sul, during the entire period of application of the NEDOCS, a maximum score of 200 (dangerously overcrowded) was obtained, as a patient was hospitalized during all the days on which the scale was measured. This patient had been in the ED for 25 days, waiting for endoscopic retrograde cholangiopancreatography (ERCP) and requiring minimal care, which occurs frequently in that hospital. The reason for the patient's stay is that in ED diagnostic examinations can be faster than when they are elective. This specific situation exemplifies what happens in many parts of Brazil. This specific situation exemplifies what happens in many parts of Brazil.

The length of stay of this patient had a strong impact on the final score of the NEDOCS scale, since the variable "Longest admit boarding time in ED (in hours)" subsequently increased during the period of application of the scale. Therefore, it can be concluded that prolonged stay in the ED due to the long time taken to carry out tests, such as ERCP compromise the quality of care provided, as a bed that could be made available to patients with higher levels of complexity was occupied.

When variables are assessed independently, it is possible to identify bottlenecks that persist in keeping scores high, and this makes it easier to adopt measures that reduce the scores with a consequent improvement in the overcrowding issue.

The application of the NEDOCS scale mainly by the researcher present in the study setting, which is justified by the work overload of ED professionals, reinforces the reality experienced in this type of service. 
Table 3 - Association of the variables with the classification of the NEDOCS scale. Porto Alegre, Brazil

\begin{tabular}{|c|c|c|c|c|c|c|c|}
\hline Variables & $\begin{array}{c}\text { Total } \\
\text { sample } \\
(n=107)\end{array}$ & $\begin{array}{l}\text { Busy } \\
(n=9)\end{array}$ & $\begin{array}{l}\text { Extremely } \\
\text { busy, but not } \\
\text { overcrowded } \\
(n=19)\end{array}$ & $\begin{array}{l}\text { Overcrowded } \\
(n=25)\end{array}$ & $\begin{array}{c}\text { Severely } \\
\text { overcrowded } \\
(n=12)\end{array}$ & $\begin{array}{c}\text { Dangerously } \\
\text { overcrowded } \\
(n=42)\end{array}$ & $\mathbf{P}$ \\
\hline Hospital - n (\%) & & & & & & & $<0.001$ \\
\hline $\begin{array}{l}\text { Hospital where } \\
\text { the study } \\
\text { was conducted }\end{array}$ & $36(33.6)$ & $0(0.0)$ & $0(0.0)$ & $0(0.0)$ & $0(0.0)$ & $36(100)^{*}$ & \\
\hline Others & $71(66.4)$ & $9(12.7)^{*}$ & $19(26.8)^{*}$ & $25(35.2)^{*}$ & $12(16.9)^{*}$ & $6(8.5)$ & \\
\hline Shift- n (\%) & & & & & & & $<0.001$ \\
\hline Morning & $24(22.4)$ & $2(8.3)$ & $2(8.3)$ & $3(12.5)$ & $1(4.2)$ & $16(66.7)^{*}$ & \\
\hline Afternoon & $29(27.1)$ & $0(0.0)$ & $2(6.9)$ & $6(20.7)$ & $8(27.6)^{*}$ & $13(44.8)$ & \\
\hline Night & $54(50.5)$ & $7(13.0)$ & $15(27.8)^{*}$ & $16(29.6)$ & $3(5.6)$ & $13(24.1)$ & \\
\hline Profession - n (\%) & & & & & & & 0.177 \\
\hline $\begin{array}{l}\text { Management } \\
\text { support NIR }\end{array}$ & $3(2.8)$ & $0(0.0)$ & $0(0.0)$ & $0(0.0)$ & $0(0.0)$ & $3(100)$ & \\
\hline Nurse & $100(93.5)$ & $8(8.0)$ & $18(18.0)$ & $25(25.0)$ & $11(11.0)$ & $38(38.0)$ & \\
\hline Physiotherapist & $1(0.9)$ & $0(0.0)$ & $0(0.0)$ & $0(0.0)$ & $1(100)$ & $0(0.0)$ & \\
\hline Physician & $2(1.9)$ & $1(50.0)$ & $1(50.0)$ & $0(0.0)$ & $0(0.0)$ & $0(0.0)$ & \\
\hline Nursing Technician & $1(0.9)$ & $0(0.0)$ & $0(0.0)$ & $0(0.0)$ & $0(0.0)$ & $1(100)$ & \\
\hline
\end{tabular}

\section{Institutions where they perform their duties - n (\%)}

$<0.001$

Philanthropic and/or attached

to the SUS

$\begin{array}{lllll}41(38.3) & 5(12.2) & 11(26,8) & 19(46.3)^{*} & 6(14.6)\end{array}$

\begin{tabular}{lcccccc}
\hline Private & $13(12.1)$ & $0(0.0)$ & $2(15.4)$ & $5(38.5)$ & $5(38.5)^{*}$ & $1(7.7)$ \\
\hline Public & $48(44.9)$ & $2(4.2)$ & $3(6.3)$ & $1(2.1)$ & $1(2.1)$ & $41(85.4)^{*}$ \\
\hline Others & $5(4.7)$ & $2(40.0)^{*}$ & $3(60.0)^{*}$ & $0(0.0)$ & $0(0.0)$ & $0(0.0)$ \\
\hline
\end{tabular}




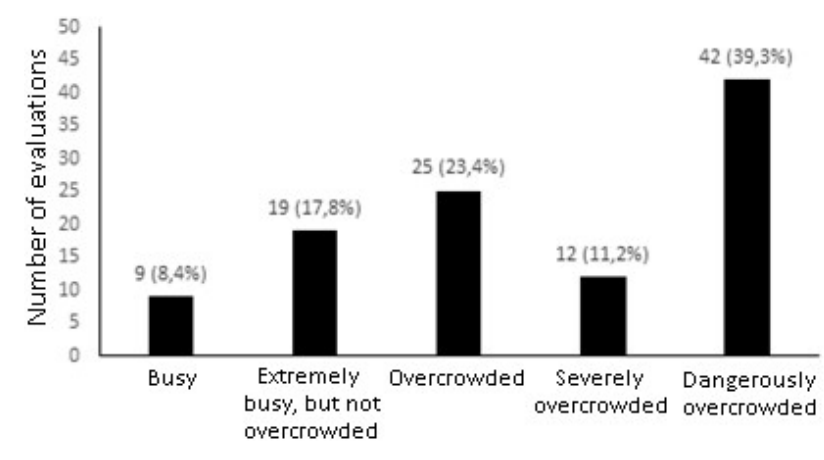

Score classification

Graph 1 - Classification of ED capacity levels according to a Correction factor of 0.5 . Porto Alegre, Brazil

Source: Research data, 2019

\section{CONCLUSION}

The present study performed the translation and cross-cultural adaptation of the NEDOCS scale, bringing credibility to the tool and ensuring that it is used correctly and in accordance with the developer's recommendation. The cross-cultural adaptation of the NEDOCS scale to the Portuguese language has conceptual, semantic, cultural and operational equivalence with the original items, and its application in Brazilian Emergency Services in clinical practice and research is feasible.

A limitation of this study was the fact that the names of the institutions where the tool was applied were not made available, and thus it is not possible to explain that the study was carried out in different regions of the country. Moreover, few health professionals in the main study setting agreed to participate in the application of the NEDOCS scale, and the main justification was work overload in ED.

The NEDOCS scale can be used as a tool for the analysis of management indicators in hospital emergency services. Its variables make it possible to identify overcrowding and implement measures to reduce scores, and consequently improve the levels of capacity in these services.

This is an unprecedented study, which describes a process to obtain equivalence between the original version and the final version, which is essential to guarantee the reliability of the findings. Hence this study makes it possible to create a website and/or smartphone application, aimed to provide a more practical use of the scale, which can stimulate other studies on the use of the tool to improve ED flows. The NEDOCS scale can also be used in digital indicator assessment tools to draw attention to the need for monitoring ED capacity levels, favoring more efficient patient flows, in order to reduce ED overcrowding.

\section{REFERENCES}

1. Momeni M, Vahidi E, Seyedhosseini J, Jarchi A, Naderpour Z, Saeedi M. Emergency overcrowding impact on the quality of care of patients presenting with acute stroke. Adv J Emerg Med. 2017;2(1):e3. doi: https://doi. org/10.22114/AJEM.v0i0.25

2. Oliveira GS, Jesus RM, Lima DM, Mendonça IO, Ribeiro HL. Superlotação das urgências e estratégias de gestão da crise: uma revisão da literatura. Cad Grad: Ciênc Biol Saúde Unit. 2017 [cited 2019 Aug 04];4(2):115-26. Available from: https://periodicos.set.edu.br/cadernobiologicas/article/view/4596/2498

3. Cassettari SSR, Mello ALSF, Demanda e tipo de atendimento realizado em unidades de pronto atendimento do município de Florianópolis, Brasil. Texto Contexto Enferm. 2017;26(1):e3400015. doi: https://doi. org/10.1590/0104-07072017003400015

4. Tudela P, Mòdol JM. La saturación en los servicios de urgências hospitalários. Emergencias. 2015 [citado 2019 jul 25];27(2):113-20.Disponible en: https:// dialnet.unirioja.es/servlet/articulo?codigo $=5388440$

5. Yarmohammadian MH, Rezaei F, Haghshenas A, Tavakoli N. Overcrowding in emergency departments: a review of strategies to decrease future challenges. J Res Med Sci. 2017;22:23. doi: https://doi.org/10.4103/1735-1995.200277

6. Weiss SJ, Derlet R, Arndahl J, Ernst AA, Richards J, Fernandez-Frankelton $M$, et al. Estimating the degree of emergency department overcrowding in academic medical centers: results of the National ED Overcrowding Study (NEDOCS). Acad Emerg Med. 2004;11(1):38-50. doi: https://doi.org/10.1197/j. aem.2003.07.017

7. Garcia-Romero M, Rita-Gáfaro CG, Quintero-Manzano J, Angarita AB. NEDOCS vs subjective evaluation, $i$ is the health personnel of the emergency department aware of its overcrowding? Colomb Med. 2017 [cited 2020 Jun 03]; 48(2):53-5. Available from: http://www.scielo.org.co/scielo. php?script=sci_arttext\&pid=\$1657-95342017000200053\&lng=en

8. Hospital de Clínicas de Uberlândia (BR) [Internet]. Uberlândia (MG); C20182020 [cited 2020 Apr 10] Projeto reduz superlotação nas emergências dos hospitais; [about 1 screen]. Available from: https://www.hc.ufu.br/noticia/ projeto-reduz-superlotacao-emergencias-hospitais

9. Beaton DE, Bombardier C, Guillemin F, Ferraz MB. Guidelines for the process of cross-cultural adaptation of self-report measures. Spine. 2000;25(24)3186-91. doi: https://doi.org/10.1097/00007632-200012150-00014

10. Coordenação de Aperfeiçoamento de Pessoal de Nível Superior (BR) . Portaria n 206 de 4 de setembro de 2018. Dispõe sobre obrigatoriedade de citação da CAPES. Diário Oficial da União, 2018 set 05 [cited 2020 Jun 03];155(172 Seção 1):22. Available from: https://pesquisa.in.gov.br/imprensa/jsp/visualiza/index. jsp?data $=05 / 09 / 2018 \&$ jornal $=515 \&$ pagina $=22$

11. Weiss SJ, Ernst AA, Derlet R, King R, Bair A, Nick TG. Relationship between the National ED Overcrowding Scale and the number of patients who leave without being seen in an academic ED. Am J Emerg Med. 2005;23(3):288-24. doi: https://doi.org/10.1016/j.ajem.2005.02.034 
12. Coluci MZO, Alexandre NMC, Milani D. Construção de instrumentos de medida na área da saúde. Ciênc Saúde Coletiva. 2015;20(3):925-36. doi: https://doi. org/10.1590/1413-81232015203.04332013

13. Polit DF, Beck CT. Fundamentos de pesquisa em enfermagem: avaliação de evidências para a prática da enfermagem. 9. ed. Porto Alegre: Artmed; 2019.

14. Skinner J. Forecasting Emergency Department Overcrowding. SPNHA Rev. 2016 [cited 2019 Jun 14];12(1):96-109. Available from: https://scholarworks.gvsu. edu/cgi/viewcontent.cgi?article=1056\&context=spnhareview

15. Pereira RDM, Alvim NAT. Delphi technique in dialogue with nurses on acupuncture as a proposed nursing intervention. Esc Anna Nery. 2015 [cited 2020 jun 03];19(1):174-80. Available from: https://www.scielo.br/scielo. php?script=sci_arttext\&pid=\$1414-81452015000100174\&lng=en\&nrm=i so\&tlng=en

16. Streiner DL, Norman GR, Cairney J. Health measurement scales: a practical guide to their development and use.5th ed. New York: Oxford University Press; 2014.

\section{- Acknowledgments:}

We thank the Coordination for the Improvement of Higher Education Personnel (CAPES), the Federal Nursing Council (COFEN) and Universidade do Vale do Rio dos Sinos (UNISINOS) for the opportunity to carry out the Professional Master's Program in Nursing with full- tuition fellowship under CAPES/COFEN Agreement - Notice 27/2016.

\section{- Authorship contribution:}

Conceptualization - Henrique Meirelles Boldori, Rosane Mortari Ciconet.

Data curation - Henrique Meirelles Boldori, Rosane

Mortari Ciconet.

Formal analysis - Henrique Meirelles Boldori, Rosane

Mortari Ciconet.

Methodology - Henrique Meirelles Boldori, Rosane

Mortari Ciconet, Márcio Neres dos Santos, Rafaela

Schaefer, Karin Viegas.

Writing - review and editing - Henrique Meirelles

Boldori, Rosane Mortari Ciconet, Márcio Neres dos

Santos, Rafaela Schaefer, Karin Viegas.

\section{- Corresponding author:}

Henrique Meirelles Boldori

E-mail: henriquem.b@hotmail.com
17. Innes G, Sivilotti M, Ovens H, Mclelland K, Dukelow A, Kwok E, Chochinov A. Emergency overcrowding and access block: A smaller problem than we think. CJEM Can J Emerg Med. 2018 [cited 2019 Aug 02];21(2):177-85. Available from: $\quad$ https://www.cambridge.org/core/journals/canadian-journal-ofemergency-medicine/article/emergency-overcrowding-and-access-block-asmaller-problem-than-we-think/3FA77977905316AAFC7A2B706C478825

18. Kimberley BV, Maryse C, Pleunie PMR, Ewout WS, Suzanne P, Hester FL. Emergency department overcrowding: a survey among European neurotrauma centres. Emerg Med J. 2018;35(7):447-4. doi: https://doi.org/10.1136/ emermed-2017-206796

19. Cavalcanti PB, Ely VHMB, Jeremias DM, Schneider JP, Silva MV, et al. Avaliação pós-ocupação de unidades de emergência hospitalares de Florianópolis: problemas recorrentes e possíveis soluções. Ambient Constr. 2019;19(2):17186. doi: https://doi.org/10.1590/s1678-86212019000200315 